\title{
NAMA-NAMA GENG SEKOLAH DI YOGYAKARTA: KAJIAN LINGUISTIK ANTROPOLOGI
}

\author{
Sudaryanto \\ Program Studi Pendidikan Bahasa dan Sastra Indonesia \\ FKIP Universitas Ahmad Dahlan \\ Jalan Pramuka 42, Sidikan, Umbulharjo, Kota Yogyakarta, DIY 55161 \\ Sudaryanto82@yahoo.com
}

\begin{abstract}
Abstrak
Salah satu fenomena sosial di kalangan remaja saat ini ialah terbentuknya geng-geng sekolah. Di Yogyakarta, nama-nama geng sekolah, baik di tingkat Sekolah Menengah Pertama (SMP) maupun Sekolah Menengah Atas (SMA) sederajat, dinilai cukup unik dan menarik. Tujuan penelitian ini ialah mengkaji nama-nama geng sekolah di Yogyakarta dalam kajian linguistik antropologi (anthropological linguistics). Teknik pengumpulan data dalam penelitian ini menggunakan peneliti sebagai instrumen utama penelitian. Data yang dikumpulkan adalah nama-nama geng sekolah di Yogyakarta yang disimak dan dicatat oleh peneliti. Teknik analisis data yang digunakan dalam penelitian ini ialah teknik kajian isi (content analysis) secara objektif dan sistematis. Adapun hasil penelitian ini ialah adanya fenomena kebahasaan yang meliputi (1) penggunaan akronim, (2) resistansi bahasa, (3) pemakaian bahasa Jawa, (4) pemakaian bahasa Inggris, dan (5) pemakaian istilah militer di balik namanama geng sekolah di Yogyakarta.
\end{abstract}

Kata Kunci: nama geng sekolah, linguistik antropologi, fenomena kebahasaan

\begin{abstract}
One of the social phenomena among teenagers today is the formation of school gangs. In Yogyakarta, the names of school gangs, both at junior high school (SMP) and senior high school (SMA) level, are considered unique and interesting. The purpose of this study is to examine the names of school gangs in Yogyakarta from the prespective of anthropological linguistic studies. Data collection techniques in this study involve the researcher as the main instrument of research. The data collected were the names of school gangs in Yogyakarta that were observed and recorded by the researchers. The data analysis technique used in this research is the content study technique, objectively and systematically. For the results of this study is the existence of linguistics phenomena which include (1) the use of acronyms, (2) language resistance, (3) use of Javanese (bahasa Jawa), (4) use of English, and (5) use of military terms, behind the names of school gangs in Yogyakarta.
\end{abstract}

Keywords: names of school gangs, anthropological linguistics, linguistics phenomenon

\section{Pendahuluan}

Harian Kompas, edisi Sabtu, 14 Januari 2017, hlm. 15, memberitakan bahwa Majelis hakim Pengadilan Negeri Bantul, Daerah Istimewa Yogyakarta, Jumat (13/1), menjatuhkan 
hukuman 3-5 tahun penjara kepada 10 pelajar. Mereka adalah terdakwa pelaku kekerasan yang menewaskan siswa SMA Muhammadiyah 1 Yogyakarta, Adnan Wirawan Ardianto. Dari 10 pelajar itu, 2 pelajar yang dinilai menjadi pelaku utama kekerasan adalah Ke (17 tahun) dan Em (16 tahun). Keduanya dijatuhi hukuman masing-masing 5 tahun penjara.

Lebih lanjut diberitakan, pelaku Pa (17 tahun) dijatuhi hukuman 4 tahun penjara. Tujuh pelaku, yakni Ro (16 tahun), St (15 tahun), Dw (17 tahun), Ma (16 tahun), Ne (16 tahun), Ca (16 tahun), dan De (16 tahun), dijatuhi hukuman masing-masing 3 tahun penjara. Para pelaku juga dihukum menjalani pelatihan kerja selama 3 bulan. Kesepuluh pelajar itu dinyatakan melanggar Pasal 80 Ayat 3 juncto Pasal 76C Undang-Undang (UU) Nomor 35 Tahun 2014 tentang Perubahan atas UU No 23/2002 tentang Perlindungan Anak.

Salah satu makna yang dapat dipetik adalah aksi kekerasan oknum pelajar masih terjadi hingga kini, termasuk di Yogyakarta yang dijuluki sebagai Kota Pendidikan atau Kota Pelajar. Aksi tersebut memang disebabkan oleh banyak faktor. Satu di antaranya adalah terbentuknya geng sekolah. Geng sekolah merupakan salah satu fenomena sosial di kalangan remaja saat ini. Bisa jadi, peristiwa kekerasan yang dialami oleh Adnan dan kawan-kawannya karena faktor permusuhan geng sekolah pelaku dengan geng SMA Muhammadiyah 1 Yogyakarta.

Faktor permusuhan geng antarsekolah, disadari atau tidak, sesungguhnya melibatkan unsur bahasa, baik bahasa verbal maupun bahasa nonverbal (Sudaryanto, 2016, p. 1\&7). Bahasa verbal diwujudkan dengan aksi vandalisme atau corat-coret di dinding rumah atau fasilitas umum (lihat Gambar 1). Sementara itu, bahasa nonverbal diwujudkan dengan tatapan dan bahasa tubuh (body language) ketika para oknum pelajar bertemu di jalan. Dari kedua jenis bahasa itu, yang menjadi fokus kajian ini adalah bahasa verbal berupa namanama geng sekolah.

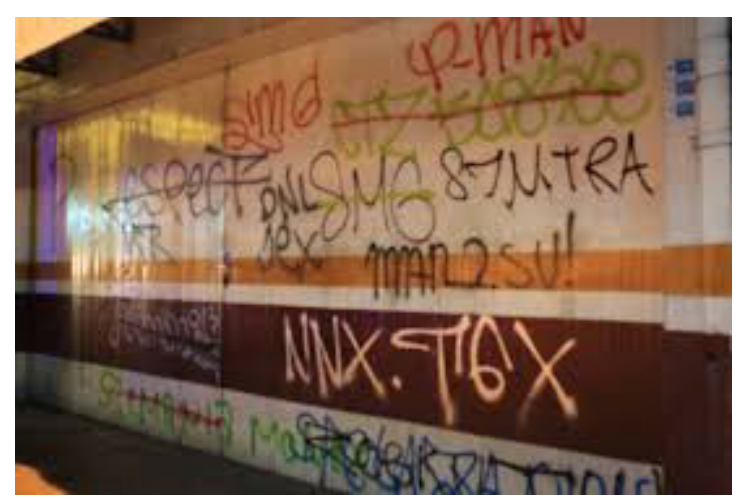

Gambar 1. Contoh Vandalisme di Yogyakarta

Di Yogyakarta, nama-nama geng sekolah, baik di tingkat Sekolah Menengah Pertama (SMP) maupun Sekolah Menengah Atas (SMA) sederajat, dinilai cukup unik dan menarik. Nama-nama geng sekolah itu ternyata tidak sekadar urusan nama, tetapi juga mencerminkan adanya fenomena kebahasaan yang berhubungan dengan kelompok sosial, agama, dan pekerjaan. Oleh karena itu, amat menarik jika nama-nama geng sekolah tadi ditinjau dari kajian linguistik antropologi atau antropologi linguistik.

Menurut Kridalaksana (2011, p. 144), linguistik antropologi adalah cabang linguistik yang mempelajari variasi dan penggunaan bahasa dalam kebudayaan dan ciri-ciri bahasa yang berhubungan dengan kelompok sosial, agama, pekerjaan, atau kekerabatan. Sementara Lauder \& Lauder (2007, p. 231) menjelaskan antropologi linguistik adalah salah satu cabang linguistik yang menelaah hubungan antara bahasa dan budaya, terutama untuk mengamati bagaimana bahasa itu digunakan sehari-hari sebagai alat dalam tindakan bermasyarakat. 
Adapun peranti-peranti bahasa yang digunakan mencakup (1) akronim, (2) resistansi bahasa, (3) bahasa Jawa, (4) bahasa Inggris, dan (5) istilah militer. Menurut Kridalaksana (2011, p. 5), akronim adalah kependekan yang berupa gabungan huruf atau suku kata atau bagian lain yang ditulis dan dilafalkan sebagai kata yang sesuai dengan kaidah fonotaktik bahasa bersangkutan. Misalnya, ABRI (Angkatan Bersenjata Republik Indonesia).

Berikutnya, menurut Halliday (dalam Wijana, 2014, p. 61), resistansi bahasa sama dengan istilah "Anti-language" untuk menyebut bahasa khusus yang digunakan oleh kaum terdominasi. Anti-language pada hakikatnya merupakan bentuk perlawanan dari kelompokkelompok yang bertindak represif. Oleh karena itu, bentuk-bentuk pemakaian bahasa di dalam masyarakat, seperti slang, permainan bahasa pada anak-anak, termasuk nama-nama geng sekolah, adalah pemberontakan terhadap bahasa standar yang diajarkan oleh pihak guru di sekolah dan orang tua di rumah.

Sementara itu, menurut Sudaryanto (2017), bahasa Jawa merupakan salah satu bahasa daerah di Indonesia. Bahasa Jawa memiliki jumlah penutur di dunia sebanyak 65 juta orang, sedangkan bahasa Inggris memiliki jumlah penutur di dunia sebanyak 350 juta orang (Comrie via Montolalu, dkk, 2007, p. 185-186). Istilah militer merupakan kosakata yang digunakan di lingkungan atau kalangan militer, khususnya di Indonesia.

\section{Metode Penelitian}

Metode penelitian yang digunakan dalam kajian ini adalah metode analisis konten (Krippendorf, 1980, p. 21). Penelitian tentang nama-nama geng sekolah di Yogyakarta pada umumnya merupakan analisis isi pesan yang tercermin dari nama-nama geng tersebut. Oleh karena itu, kajian ini bersifat deskriptif yang memerikan tentang nama-nama geng sekolah di Yogyakarta. Masalah nama-nama geng sekolah di Yogyakarta itu akan dianalisis dari perspektif linguistik antropologi yang memadukan faktor kelompok sosial, agama, pekerjaan, atau kekerabatan.

Desain yang digunakan dalam penelitian ini yang merupakan estimasi terhadap gejala yang terdapat pada data. Pola kepriyayian yang akan dideskripsikan menyangkut beberapa gejala, maka parameter yang digunakan juga meliputi beberapa parameter sesuai gejala yang dideskripsikan. Jika diskemakan dapat digambarkan berikut.
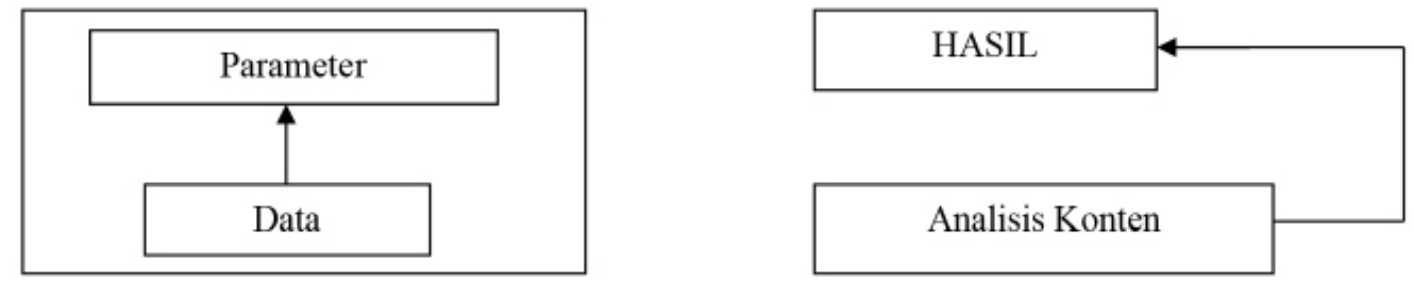

Pengumpulan data dilakukan dengan teknik membaca dan mencatat secara cermat nama-nama geng sekolah di Yogyakarta yang dijadikan contoh melalui kartu data. Namanama geng sekolah di Yogyakarta dicatat dari sumber laman http://almuzakk.blogspot. co.id/2012/03/nama-nama-geng-sma-di-jogja.html? $\mathrm{m}=1$ dan tulisan di tembok (vandalisme). Kartu data dibagi dua kelompok, yaitu (1) kelompok yang mendeskripsikan tentang namanama geng sekolah di tingkat Sekolah Menengah Pertama (SMP) dan (2) kelompok yang mendeskripsikan tentang nama-nama geng sekolah di tingkat Sekolah Menengah Atas (SMA).

Validitas yang digunakan dalam penelitian ini adalah validitas semantik, jika data yang muncul perihal nama-nama geng sekolah di Yogyakarta memiliki fenomena kebahasaan 
berupa penggunaan akronim, resistansi bahasa, pemakaian bahasa Jawa, pemakaian bahasa Inggris, dan pemakaian istilah militer. Reliabilitas yang digunakan adalah reliabilitas interrater, yaitu mengonsensuskan hasil penelitian dengan pakar linguistik (bahasa Indonesia dan bahasa Jawa).

Data dianalisis dengan teknik analisis konten dengan prosedur (a) pencatatan, (b) reduksi data, (c) pengkategorian, dan (d) inferensi. Pencatatan dilakukan dengan kartu data. Unit data diambil dari unit kata atau kosakata yang mencerminkan nama-nama geng sekolah di Yogyakarta. Proses analisisnya dilakukan dengan alur (1) pemahaman isi nama-nama geng sekolah di Yogyakarta, (2) identifikasi nama-nama geng sekolah di Yogyakarta berdasarkan fenomena kebahasaan berupa penggunaan akronim, resistansi bahasa, pemakaian bahasa Jawa, pemakaian bahasa Inggris, dan pemakaian istilah militer, dan (3) klasifikasi namanama geng sekolah di Yogyakarta berdasarkan fenomena kebahasaan. Setelah klasifikasi data yang belum terstruktur, ditata dan disaring dengan membuang data-data yang kurang relevan dengan tujuan penelitian. Pada tahap inferensi, dilakukan interpretasi fenomena kebahasaan di balik nama-nama geng sekolah di Yogyakarta.

\section{Hasil dan Pembahasan}

Di bagian ini dipaparkan hasil-hasil temuan tentang nama-nama geng sekolah di Yogyakarta dilihat dari kajian linguistik antropologi. Secara berturut-turut akan dibahas di bawah ini fenomena kebahasaan di balik nama-nama geng sekolah di Yogyakarta, baik di tingkat Sekolah Lanjutan Tingkat Pertama (SLTP) maupun di Sekolah Menengah Atas (SMA), yaitu penggunaan akronim, resistansi bahasa, pemakaian bahasa Jawa, pemakaian bahasa Inggris, dan pemakaian istilah militer.

\subsection{Penggunaan Akronim}

Nama-nama geng sekolah di Yogyakarta umumnya menggunakan akronim. Akronim adalah kependekan yang berupa gabungan huruf atau suku kata atau bagian lain yang ditulis dan dilafalkan sebagai kata yang wajar. Misalnya, letkol letnan kolonel, rudal peluru kendali, dan Kowani Kongres Wanita Indonesia. Di bawah ini, berturut-turut dibahas jenis-jenis akronim pada nama-nama geng sekolah di Yogyakarta.

a. Gabungan Huruf-Huruf Pertama

Sejumlah data berupa nama-nama geng sekolah di Yogyakarta menggunakan akronim berupa gabungan huruf-huruf pertama dari kata-kata yang membentuk konsep itu. Misalnya:
1) SMC, Sunday Morning Cartoon (SMAN 4 Yogyakarta)
2) REM, Ras Eleven Mania (SMAN 11 Yogyakarta)
3) RIB, Revolution In Boda (SMA Bopkri 2 Yogyakarta)
4) GMH, Gajah Mada Hooligans (SMA Gajah Mada)

b. Gabungan Suku Kata Pertama dari Kata

Data berupa nama geng sekolah di Yogyakarta menggunakan akronim berupa gabungan suku kata pertama dari kata-kata yang membentuk konsep itu. Misalnya:

\section{5) Palu, Pangudi Luhur (SMA Pangudi Luhur)}

Data (5) berupa nama geng sekolah di Yogyakarta yang menggunakan akronim berupa gabungan suku kata pertama dari kata Pangudi dan Luhur. Namun demikian, nama 
geng ini kerapkali diganti dengan nama Hammer, kata bahasa Inggris untuk palu. Barangkali, nama Hammer jauh lebih keren daripada nama Palu.

c. Gabungan Huruf Pertama dan Suku Kata Pertama dari Kata

Sejumlah data berupa nama-nama geng sekolah di Yogyakarta menggunakan akronim berupa gabungan huruf pertama dan suku kata pertama atau sebaliknya dari kata-kata yang membentuk konsep itu. Misalnya:

6) Oestad, Oerganisasi Siswa Taat Darus (SMA Muhammadiyah 1 Yogyakarta)

7) Ranger, Remaja Alim Neng Gelem Rusuh (SMA Muhammadiyah 2 Yogyakarta)

8) Grixer, Gerakan Remaja Islam Xeneng Rusuh (SMA Muhammadiyah 3 Yogyakarta)

Pada data (6) kata Organisasi diubah menjadi Oerganisasi agar menjadi kata Oestad, bukan Orstad. Oestad merupakan penulisan dengan ejaan Suwandi atau ejaan Republik, yaitu huruf $u$ ditulis oe. Kata darus bersinonim dengan daras, artinya 'membaca Alquran dengan lantang untuk berlatih melancarkan bacaan'. Ustaz (yang tidak baku, Ustad atau Ustadz) itu sendiri bermakna 'guru agama atau guru besar (lakilaki)'. Namun, kegiatan geng sekolah, Oestad, ternyata tidak sesuai dengan pandangan tentang ustaz yang penceramah agama Islam.

Data (7) dan (8) memiliki kemiripan dalam hal pengakronimannya. Data (7) mengambil tiap-tiap huruf awal pada kata-kata yang membentuk konsep, yaitu $R, A, N$, dan $R$. Sementara itu, kata gelem (bahasa Jawa, 'mau') terambil dari suku kata pertama ge diikuti -lem. Data (8) tak jauh berbeda dengan data (7), yang diambil tiap-tiap huruf awal pada kata-kata mendukung konsep itu. Misalnya, huruf $G, R, I$, dan $R$. Kata Xeneng itu wujud resistansi atas kata seneng (senang), dan diambil dari suku kata xedan -neng.

\subsection{Resistansi Bahasa}

Bila dikaitkan dengan nama-nama geng sekolah di Yogyakarta, bentuk resistansi bahasa jelas sekali tampak pada penggunaan bahasa Indonesia, bahasa daerah, dan bahasa Inggris yang maknanya disimpangkan atau dieja secara tidak semestinya. Sebagai bentuk perlawanan terhadap bahasa Indonesia, bahasa daerah, dan bahasa Inggris, misalnya, huruf $s$ diubah menjadi $z, x$, atau $z t$; b diubah menjadi $\mathrm{b}$; dan $j$ diubah menjadi $z$ atau $z h$, seperti terlihat dalam nama-nama geng sekolah berikut:

4) Ganza, Sagan Zatoe (SMAN 9 Yogyakarta)

5) Regazt, Remaja Gama Berzatu (SMA Tiga Maret/Gama)

6) Bradiz, Brandalan Diziplin (SMA UII, Yogyakarta)

7) NBZ, Night BoyZ, (SMA Bopkri I Yogyakarta)

8) Morenza, Moega Rajane Zogja (SMK Muhammadiyah 3 Yogyakarta)

9) Grixer, Gerakan Remaja Islam Xeneng Rusuh (SMA Muhammadiyah 3 Yogyakarta)

10) Respect Praza, Remaja Suka Cita Penuh Canda Tawa Prambanan Zatoe (SMAN 1 Prambanan)

11) Zprin, Zerdadu Perindustrian (SMK Perindustrian)

12) Vozter, Revolution Zhetis Loro (SMKN 3 Yogyakarta [d/h STM 2 Yogyakarta)

13) Geneb [genep, bahasa Jawa 6] (SMAN 6 Yogyakarta)

14) ZLORZ, Zekolah Lor Zamzat (SMPN 14 Yogyakarta) 
15) Molazt [limolas, bahasa Jawa 15] (SMPN 15 Yogyakarta)

\subsection{Pemakaian Bahasa Jawa}

Nama-nama geng sekolah di Yogyakarta memakai kosakata bahasa Jawa, terutama yang menunjukkan angka dan arah. Kedua hal itu sering dipakai oleh orang Jawa dalam kehidupan sehari-hari. Sebagai contoh, bahasa Jawa ragam ngoko angka: siji (1), loro (2), telu (3), papat (4), limo (5), dan seterusnya. Sementara itu, bahasa Jawa ragam ngoko arah: kulon (barat), wetan (timur), lor (utara), dan kidul (selatan). Selain itu, ada pula pemakaian bahasa Jawa yang menunjukkan kata sifat, yaitu gelem 'mau' dan seneng 'senang', dan struktur frasa bahasa Jawa (nomina $+n e$ ), seperti rajane 'rajanya'. Mari kita perhatikan nama-nama geng sekolah di Yogyakarta yang memakai bahasa Jawa ragam ngoko berikut ini.

16) Geneb/GNB [genep, bahasa Jawa 6] (SMAN 6 Yogyakarta)

17) Ranger, Remaja Alim Neng Gelem Rusuh (SMA Muhammadiyah 2 Yogyakarta)

18) Grixer, Gerakan Remaja Islam Xeneng Rusuh (SMA Muhammadiyah 3 Yogyakarta)

19) Vozter, Revolution Zhetis Loro (SMKN 3 Yogyakarta)

20) Morenza, Moega Rajane Zogja (SMK Muhammadiyah 3 Yogyakarta)

21) Speroga, SMP Loro Gamping (SMPN 2 Gamping)

22) ZLORZ, Zekolah Lor Zamzat (SMPN 14 Yogyakarta)

\subsection{Pemakaian Bahasa Inggris}

Sejumlah data nama-nama geng sekolah di Yogyakarta memakai kosakata dan struktur frasa bahasa Inggris. Misalnya, revolution dari kata bahasa Indonesia, revolusi dan hooligans 'pendukung, fans'. Kemudian, frasa bahasa Inggris night boys, 'anak-anak malam' untuk nama geng NBZ, Night BoyZ. Penggunaan bahasa Inggris, baik dalam bentuk kosakata maupun struktur frasa, mungkin didorong oleh anggapan bahwa nama geng dalam bahasa Inggris itu lebih keren dan mentereng. Nama-nama geng sekolah di Yogyakarta itu menunjukkan ke arah tersebut, misalnya Vozter, Grixer, Ranger, Morenza, Respect, dan Regazt. Mari kita perhatikan nama-nama geng sekolah di Yogyakarta yang memakai bahasa Inggris di bawah ini.

1) SMC, Sunday Morning Cartoon (SMAN 4 Yogyakarta)

2) Roever, Repoeblik Five Revolution (SMAN 5 Yogyakarta)

3) CBZ, Canteen BoyZ (SMAN 8 Yogyakarta)

4) NBZ, Night BoyZ (SMA Bopkri 1 Yogyakarta)

5) RIB, Revolution In Boda (SMA Bopkri 2 Yogyakarta)

6) GMH, Gajah Mada Hooligans (SMA Gajah Mada)

7) Manufer, MAN 2 Forever (MAN 2 Yogyakarta)

\subsection{Pemakaian Istilah Militer}

Nama-nama geng sekolah di Yogyakarta memakai istilah-istilah militer, seperti tentara, serdadu (tempur), barikade, dan markas besar. Dalam Kamus Besar Bahasa Indonesia: Pusat Bahasa Edisi Keempat (2008: 1443), tentara memiliki arti (1) 'laskar; prajurit'; (2) 'pasukan (dari orang-orang yang berkewajiban berperang)'; (3) 'kesatuan alat negara yang terdiri atas orang-orang yang terlatih berperang'; (4) 'orang yang menjadi anggota Tentara Nasional Indonesia (prajurit, bintara, perwira, dan sebagainya)'; (5) 'sesuatu yang berhubungan (bertalian) dengan angkatan bersenjata (misalnya hukum --; pendeta --)'. 
Selain tentara, ada juga serdadu (tempur), barikade, dan markas besar. Serdadu memiliki arti yang sama dengan tentara. Barikade memiliki arti 'perintang yang dibuat untuk menghambat kemajuan musuh (dalam peperangan) atau untuk melindungiu kubu-kubu pertahanan terhadap serangan musuh'. Sementara itu, markas besar memiliki arti 'markas yang terutama yang menjadi pusat markas-markas yang lain'. Ada pula istilah militer dalam bahasa Inggris, seperti squad 'pasukan' dan battle 'prajurit, tentara, serdadu'.

Pemakaian istilah-istilah militer pada nama-nama geng sekolah itu menunjukkan bahwa para oknum pelajar yang tergabung dalam geng itu ingin meniru semangat korps kalangan militer. Adapun semangat korps kalangan militer yang ditiru itu adalah rasa solidaritas antaranggota. Jika ada anggota geng yang dimusuhi anggota geng lawan/lain, rasa solidaritas anggota geng terbentuk dan kemudian melakukan pembalasan kepada geng lawan tadi. Misalnya, aksi tawuran pelajar dan/atau aksi vandalisme nama geng di dinding atau fasilitas umum.

Mari kita perhatikan nama-nama geng sekolah di Yogyakarta yang memakai istilahistilah militer di bawah ini.

23) MLB, Malibu, Markas Besar Kali Mambu (SMA Sang Timur)

24) Stemsa, Squad Team Jetis Satu (SMKN 2 Yogyakarta)

25) Zprin, Zerdadu Perindustrian (SMK Perindustrian)

26) Stepiro, Serdadu Tempur Piri Revolution (SMK PIRI 1-2)

\section{Simpulan}

Berdasarkan hasil penelitian dan pembahasan di atas, simpulan penelitian ini adalah sebagai berikut. Di Yogyakarta, nama-nama geng sekolah, baik di tingkat Sekolah Menengah Pertama (SMP) maupun Sekolah Menengah Atas (SMA) sederajat, dinilai cukup unik dan menarik. Nama-nama geng sekolah itu ternyata tidak sekadar urusan nama, tetapi juga mencerminkan adanya fenomena kebahasaan yang berhubungan dengan kelompok sosial, agama, dan pekerjaan. Fenomena kebahasaan yang dimaksud meliputi (1) penggunaan akronim, (2) resistansi bahasa, (3) pemakaian bahasa Jawa, (4) pemakaian bahasa Inggris, dan (5) pemakaian istilah militer.

\section{Daftar Pustaka}

Kompas. (2017). “10 Pelajar Divonis 3-5 Tahun Penjara”, Edisi Sabtu, 14 Januari 2017, hlm. 15.

Kridalaksana, H. (2011). Kamus Linguistik Edisi Keempat. Jakarta: PT Gramedia Pustaka Utama.

Krippendorf, K. (1980). Content Analysis: An Introduction to Its Methodology. Beverly Hills-London: Sage Publications.

Lauder, A.F. \& Lauder, M. (2007). "Berbagai Kajian Linguistik" dalam Kushartanti, dkk (peny.). Pesona Bahasa: Langkah Awal Memahami Linguistik. Jakarta: PT Gramedia Pustaka Utama.

Montolalu, L.R. \& Lauder, M. (2007). "Tipologi Bahasa dan Bahasa-Bahasa di Dunia" dalam Kushartanti, dkk (peny.). Pesona Bahasa: Langkah Awal Memahami Linguistik. Jakarta: PT Gramedia Pustaka Utama.

Sudaryanto. (2016). "Bahasa (dan) Kekerasan", Kedaulatan Rakyat, Edisi Jumat, 30 Desember 2016, hlm. 1 \& 7. 
. (2017). Kosakata dan Ungkapan Bahasa Jawa dalam Bahasa Indonesia. Yogyakarta: Samudra Biru.

Wijana, I.D.P. (2014). "Bahasa, Kekuasaan, dan Resistansinya: Studi tentang Nama-nama Badan Usaha di Daerah Istimewa Yogyakarta". Humaniora, Vol. 26, No. 1 Februari 2014, hlm. 56-64. 